\title{
W spotkaniu z tradycją muzyczną anglikańską... Jakby w przedsionku nieba!
}

Tegoroczny numer naszego pisma jest ciekawym przyczynkiem do dialogu poprzez muzykę, jaki od wielu lat prowadzi Międzynarodowa Federacja Pueri Cantores z Royal School of Church Music - Kościoła Rzymskokatolickiego z Kościołem anglikańskim. Włączył się w niego teraz także Międzyuczelniany Instytut Muzyki Kościelnej. W roku ubiegłym gościliśmy w Krakowie przedstawicieli tej szkoły i niektóre artykuły zawarte w tegorocznym numerze są tego pokłosiem. Dobrze, że muzyka jest tak doskonałym pomostem w ekumenicznym dialogu.

Pozostałe artykuły przywołują w pamięci rok Feliksa Nowowiejskiego, muzykę Karola Szymanowskiego, Franza Danziego, interpretacje René Jacobsa. Dobrze też, że możemy przeczytać o chyba najważniejszym śpiewniku kościelnym Kościoła rzymskiego, jakim jest Gotteslob, oraz o historii muzycznych przygotowań do papieskich pielgrzymek w archidiecezji krakowskiej. Numer jest także uzupełniony o komunikaty z kolejnych Dni Muzyki Kościelnej w archidiecezji krakowskiej i raport muzyczny ze Światowych Dni Młodzieży. Niezmiernie ciekawie zapowiada się też wprowadzony od tego numeru dział dotyczący chorału gregoriańskiego. To jeszcze jedna próba, którą podejmujemy, aby zachować - zgodnie z soborowym nauczaniem - zasadę, że chorał gregoriański jest pierwszym i bardzo ważnym śpiewem Kościoła.

Mamy wielką nadzieję, że tegoroczny numer naszego czasopisma będzie także uzupełnieniem całego dzieła muzyki kościelnej, które dokonuje się w Krakowie. Tym razem chcemy zadedykować go człowiekowi, który 16 października 2016 roku odszedł po wieczną nagrodę - dokładnie w dniach, gdy dokonujemy ostatnich korekt przed drukiem. Odszedł, by śpiewać Bogu przed Jego Obliczem. Niech ten numer naszego pisma będzie wspomnieniem Mariana Machury, człowieka, który muzyką kościelną żył i ją tworzył, zabiegał o jej jakość i wychował pokolenia muzyków kościelnych w archidiecezji krakowskiej i nie tylko. Dziękujemy mu, że tworzył fundamenty pod dzisiejszy kształt edukacji muzyków kościelnych w Krakowie. To dzieło istnieje także z jego inspiracji.

ks. dr hab. Robert Tyrała, prof. UPJP II redaktor naczelny „Pro Musica Sacra” 